\title{
DIVERSITY OF WILD MUSHROOMS IN RUPANDEHI DISTRICT, WESTERN NEPAL
}

\author{
HARI PRASAD ARYAL \\ Bhairahawa Multiple Campus, Tribhuvan University, Nepal \\ hahariprasadaryal06@gmail.com
}

\begin{abstract}
This paper highlights the one of the underappreciated natural resource of NTFPs, has high food and medicinal values. The area embraces different mycophagus ethnic communities. The work emphasized the knowledge on the use of various ways of the wild mushrooms in the different ethnic groups and communities in habiting in the district and to explore in the study area. This mycological investigation carried out in different area ranging between 90 and $1229 \mathrm{~m}$ asl in tropical deciduous riverine forest, to subtropical deciduous hill forest. The specimens are housed in the Central Department of Botany, Pathology Unit, Tribhuvan University. The collected samples represented 46 species of Basidiomycetes belongs to 32 genera, 20 families and 9 order. The mycoelements prevailing in this area need sustainable utilization and conservation.
\end{abstract}

Keywords: altitudinal gradients, edible, ethnomycology, socio-economy

\section{INTRODUCTION}

Mushrooms are cosmopolitan heterotrophic organisms. They are gill bearing, fleshy, agarics (Phillips, 1981). It bears cap and gills on the underside producing spores (Boa, 2004). Edible fruiting bodies of fungi are the mushroom and inedible or poisonous are the toadstools (Miller, 1984). They exhibit remarkable diversity in form, as in Ascomycetes and Basidiomycetes (Alexopoulos \& Mims, 1993).

Generally the growth of fruit body is controlled by different environmental and ecological factors where they retain. They appear in such place where the habitats are undisturbed and ample volume of moisture and nutrition are necessary for growth, fructification and reproduction. Anthropogenic activities, human disturbance leads to threat the growth and developments declining their production. Therefore, this study was needed to explore. So the ecological approaches were also required along with distribution. This study had to assess the abundance density and frequency of the wild mushrooms on the study area.

The investigation and study of mushrooms in Nepal started since the contribution of Lloyd (1808). Since then several botanical investigations have been done (Bhandary, 1980,1991; Hattori et al., 2002; Devkota, 2005; Panday, 2008; Manandhar \& Adhikari, 2009; Bhattarai, 2013 ). Nepal is fairly rich in macrofungi, edible as well as poisonous ones. There are 1822 species of fungi among them macro fungi are 776 species belongs to 213 genera and 77 families (Adhikari, 2000). New description after it has increased; the total numbers of mushrooms are 817 species (Adhikari, 2009; Aryal \& Budhathoki, 2013 a,b,c; Aryal et al., 2014a,b). It is expected to reach more than 3000 species due to the large variation in climatic condition and 
vegetation types (Christenson et al., 2008a). Mushrooms are famous as excellent health food enriched by good quality protein and a multitude of beneficial vitamins and minerals. It is now common to find medicinal preparations from mushrooms in various forms in the world market (Balkrishna \& Nair, 1994).

Several researchers have also reported ethnomycological uses of these NTFPs from different place of the country (Hattori et al., 2002; Devkota, 2005; Christensen et al., 2008 a, b; Manandhar \& Adhikari, 2009; Pandey, 2008; Adhikari, 2014) but the present study area has not been given significant attention.

\section{Study area}

The study area (fig. 1) is the southern belt of west Nepal and lies in, Lumbini zone. The forest vegetation is dominated by members of the Dipterocarpaceae, Combretaceae, Fagaceae and Leguminosae. The studies were focus on natural as well as community managed forest on the basis of information found from the local informant and availability of the species. The field works were conduct during the 15th to 31st May and from 1st June to $31^{\text {st }}$ October in 2011. The information was noted from the interaction with members of the individuals of ethnic groups or communities.

The study sites were divided into three categories east, center and west (on the basis of vegetation zones) and two sub categories tarai and siwalik. From each sub categories they were again narrowing down by the selection of random sampling of three sites. On the basis of the forest area, the numbers of spots to be sample were determining so as to represent 10-20 $\%$. The total of 3 spots will be sampled from each topography, ranging between latitude of $27^{\circ} 20^{\prime} 00^{\prime \prime} \mathrm{N}$ and $27^{\circ} 47^{\prime} 25^{\prime \prime} \mathrm{N}$ and between the longitude of $83^{\circ} 12^{\prime} 16^{\prime \prime} \mathrm{E}$ and $83^{\circ} 38^{\prime} 07^{\prime \prime} \mathrm{E}$ of east, center and west vegetation zone of Rupandehi district of Nepal. Altogether 6 spots were supervised. They were randomly chosen by Randomize Block Deign method (Elliott, 1971). Altitude varies between 90 and 1229 masl. The average annual rainfall is $1391 \mathrm{~m}$ (GoN, 2010). 


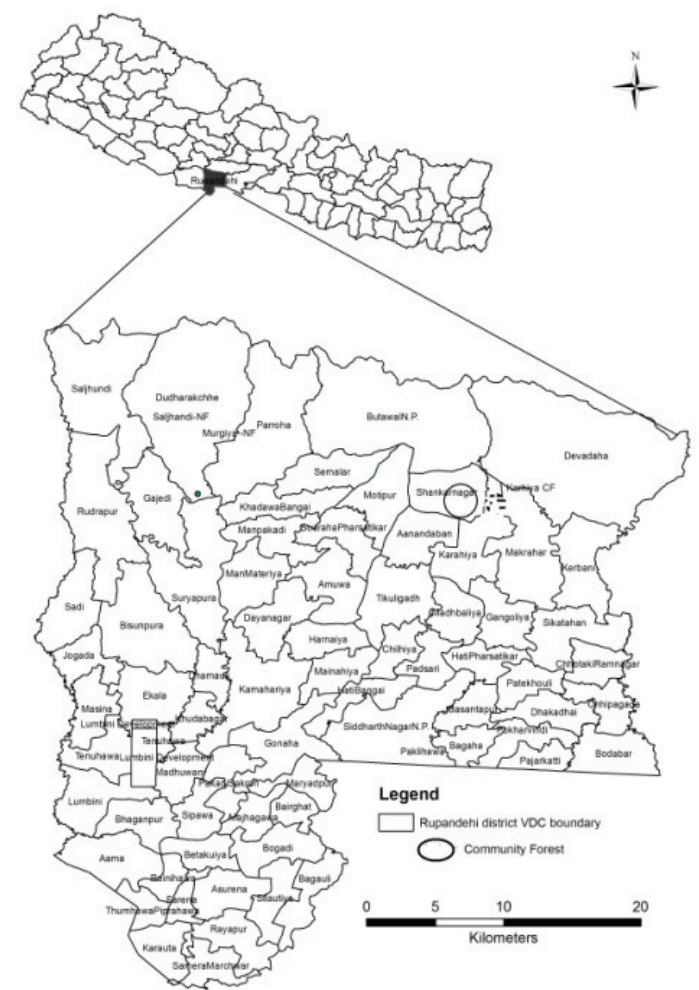

FIG. 1. Map of the sampling sites.

\section{MATERIALS AND METHODS}

\section{Sampling process}

The Participatory rural appraisal (PRA) technique (Frendenberger, 2011) was adopted with the local people aimed at getting information largely on nutritional as well as medicinal aspects. Data were obtained using combined semi-structured questionnaire, participatory discussions and field observation. For the calculation of abundance, frequency, density, and species diversity, the quadrat sizes were taken $25 \mathrm{~m} \times 25 \mathrm{~m}$. In each of the spot (forest) 10 quadrats were located by stratified random sampling method (Elliott, 1971). The frequency class was calculated by the formula:

\section{No. of Plots in which species ' $\mathrm{x}$ ' occurs $\times 100$ Total no. of plot}

Mushroom samples were photographed in their natural habitat and their morphological characters were noted. The samples were well dried in mushroom dryer (Atri et al., 2005) and packed in wax-paper bags wrapped with aluminium foil to prevent external infection and intermixing of the spores and labeled. The habitats including ecological parameters viz. altitude, vegetation 
composition, soil type, humidity, temperatures and time with macroscopic and microscopic characters of the specimens were noted. The wax-paper bags were brought to Paklihawa Campus, Institute of Agriculture and Animal Science, for further microscopic examination and followed the classification of Kuo ( 2006).

\section{Identification}

Specimens were identified with the help of relevant literatures (Bakshi, 1971; Mckenenny,1971; Svreck, 1975; Heim, 1977; Dickinson \& Lucas, 1979; Kibby, 1979; Phillips, 1981; Pacioni,1985; Purkayastha \& Chandra, 1985; Singer,1986; Imazeki et al., 1988; Kummar et al., 1990; Tulloss \& Bhandary, 1992; Adhikari, 1996; Watkinson et al., 2000) and on line data base such as: Biodiversity Library.org, Index fungorum, Jstor.org, Mycobank.org, tropicos.org).

\section{RESULTS AND DISCUSSION}

As many as 116 specimens of wild mushrooms belonging to the class Basidiomycetes were made and worked out for their macro- and micro-morphological and ethnomycological features. A total of 46 taxa of wild mushrooms belonging to 32 genera spread over 20 families, 9 orders were identified (table 1). The identified species and varieties spread over in following genera viz., Agaricus (2), Amanita (4), Armelleria (1), Asterophora (1), Auricularia (1), Bjerkandera (1), Buchwaldoboletus (1), Cantharellus (1), Coltrica (1), Coprinus (2), Daldenia (1), Flammulina (1), Ganoderma (1), Grifola (1), Guepina (1), Laetiporus (1), Lentinus (1), Leucopaxillus (1), Macrolepiota (2), Marasmius (1), Nigroporus (1), Psthyrella (1), Pycnoporus (1), Ramaria (2), Rameriopsis (1), Russula (3), Schizophyllum (1), Scleroderma (2), Sparassis (1), Termitomyces (4) Tramets (1) and Volvorella (2) were observed. Out of total collection, 50\% of mushrooms were found to be under Agaricales order followed by Polyporales, Boletales, Russulales, Tricholomatales, Claveriales, Hymanochaetales, Tramellales and Phallels. The following graphs show the pattern of diversity, frequency and dominance of the species (fig. 2).

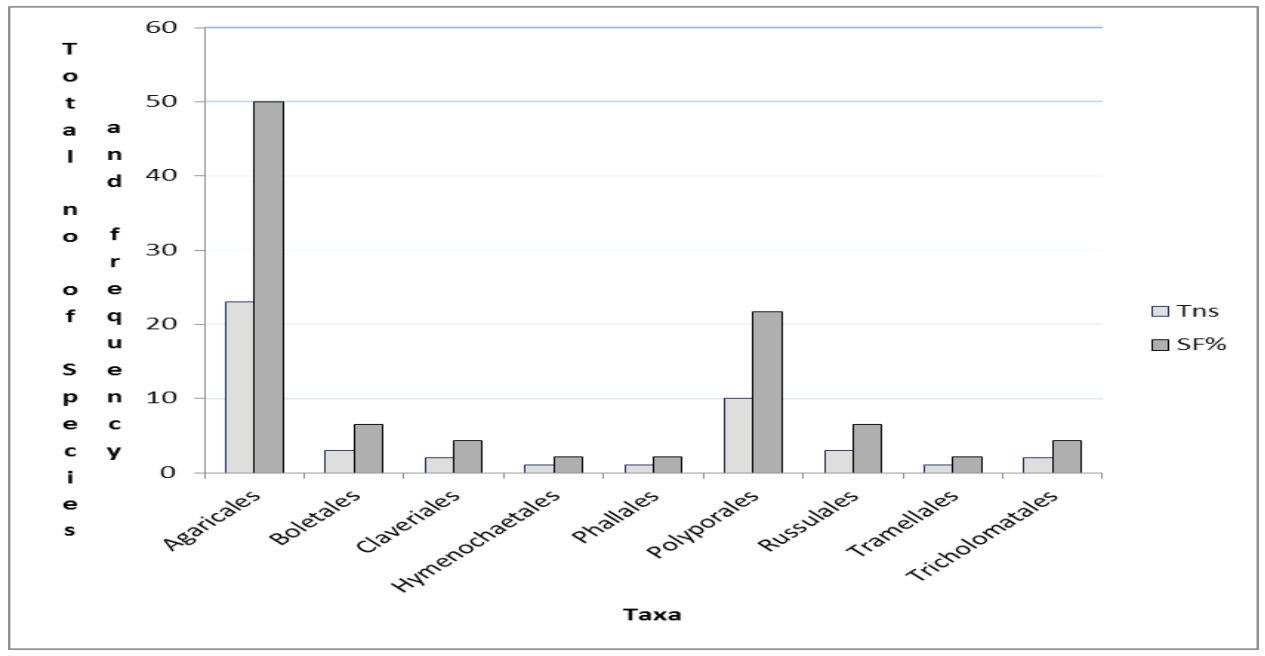

FIG. 2. The total number of species (Tns) and \% frequency of groups (SF \%) of basidiomycetes. 
Rupandehi district has rich biodiversity with its remarkable climatic variation within tropical to subtropical range. This paper is the compilation of the results from investigations done on tropical to subtropical Nepalese mycoflora. The compilation includes the species of Basidiomycota reported by earlier explorers from the nation and abroad.

Indigenous knowledge of edible mushrooms and their utilization by local population is an important component of ethnomycology, so the data were gathered during the ethnomycological survey related to collection of wild mushrooms. The results revealed that forty-six potential wild edible fleshy fungi from different locations of study area were recorded. Out of these, as many as (25) mushrooms were preferentially consumed by the native populations (10) medicinal significance, they also used as vegetable, has therapeutic use and its soup is also used as tonic (4) poisonous and (11) non-edible species of the area. Out of 57 respondents of mycophagous ethnic groups, $84 \%$ people were found to have used it for vegetable, $7 \%$ therapeutic used $5 \%$ used as tonic-syrup and $4 \%$ food.

The gathering of mushrooms shows that there are plenty of species, which are said to be edible and of medicinal value. Many mushroom species are gathered by local people for their daily livelihood and trade. The medicinally important tropical polypore like Pycnoporus cinnabarinus has been gathered for the remedy of infectious disease (Mump), Ear pain etc. The cosmopolitan species like Schizophyllum commune the inedible fungi is sometimes used for culinary proposes in food deficit condition. This species has religious value also and is used as 'Sagun' for better happening in the marriage ceremony in Newar community. Many such significant contributions in the ethnomycological studies of the macrofungi world over have been reported (Akpaja et al., 2003; Guissou et al., 2008). Therefore, the study indicates the cultural importance and long traditional use of wild mushrooms in the studied sites. The Dipterocarp inhibiting mycoelements like Scleroderma texense has been used both for food and medicine. During surveys, it was found that wild edible fleshy fungi are usually available in the village shops, highway road and town markets for sale in monsoon season. Most of the edible species are sold in fresh form while others such as Macrolepiota spp. Termitomyces spp. are put up for sale in both fresh and dried forms. These species are marketed at different rates. Macrolepiota fuliginosa, M. rhacodes, Sparassis crispa are sold @ rupees 75-100 per kg while Coprinus comatus, Ramaria aurea, $R$. falva, are available at rupees 100-125 per kg. Correspondingly, Scleroderma spp. and Termitomyces spp. were sold at marginally higher price of rupees $400-500$ per kilogram.

Many of these observations follow the earlier studies covered in ethnomycological studies include Chepang (Tullous \& Bhandary, 1992; Pandey, 2008), Sherpas (Sacherer, 1979), Tamangs (Kharel, 1999; Pandey, 2008) and Thakali (Bill \& Cotter, 1989). The geographical area covered by ethnomycological studies in Nepal includes Kathmandu (Singh,1966; Singh \& Nisha, 1974), Kathmandu valley and adjoining area (Adhikari, 2000; Pandey, 2008), Dumre, Pokhara, Mustang, Manang (Bhandary, 1991), Pokhara and Kathmandu valley (Joshi \& Joshi ,1999), Rolwaling (Sacherer, 1979), Western Central Region of Nepal (Adhikari et. al., 2005), and Sukhaura Hariyali Community forest, Rupandehi (Bhattarai, 2013). The local people collected the mushrooms in bulk and further sold these through their sale counters @ Rs. 50-150/kg. 
Several researchers have also reported the edibility and therapeutic used of these species from different place of the country (Hattori et al., 2002; Devkota, 2005; Christensen et al., 2008ab; Manandhar \& Adhikari, 2009; Pandey, 2008; Adhikari, 2014) and abroad (Harsh et al., 1993; Kamat, 1999; Atri \& Kaur, 2003; Sagar et al., 2005).

During surveys, it was found that the population of Amanita chepangiana, Macrolepiota fuliginosa, Scleroderma bovista, Sparasis crispa, species of Termitomyces and Volvorella are declining since the last two decades due to deterioration of forest.

It is visualized from the field survey that some of the important species need special attention to conserve against the threat to avoid their unmanaged and unscientific exploitation by the people. It is therefore necessary to conserve natural habitat of mushroom diversity for the sustainable development. The government should take special attention on these aspects.

The forest biodiversity has supported the livelihood of many indigenous tribal people who live in inaccessible remote area. It plays an important role for ecosystem replenishment and performs a wide variety of ecological roles. Its documentation in different social, cultural and ethno medicinal practices is very important to sensitize the communities. It plays a vital role in enrichment of the socio-economic life of the rural marginal people. Besides their consumption, the use of its in local medicines also paves the way for the upbringing new industries. This research provides enough background to appreciate the diversity and their relevance in ecosystem maintenance in general and human welfare in particular. It creates an enthusiasm towards intensive exploration on these mycoflora.

\section{ACKNOWLEDGEMENTS}

I would like to acknowledge District Development Committee, Rupandehi, Lumbini zone Nepal for providing the opportunity and support to this research work to explore the underappreciated wild state of mushroom; thanks are due to the Paklihawa Campus, IAAS Bairahawa and Central Department of Botany, Tribhuvan University for providing laboratories facilities. Sincere thanks are extended to local informants of the study area for providing information.

\section{REFERENCES}

ADHIKARI, M K (1996) Biodiversite des Basidiomycetes au Nepal: etude systematique et biogeographique. Specialite Ecologie-Mycologique. These du Doctorat de l'Universite present devant l'Universite aul Sabatier, Toulouse, France; 205 pp (In French).

ADHIKARI, M K (2000) Mushrooms of Nepal. In DURRIEU, G (ed), ADHIKARI, K S; , Laurence, O, Mycosphere, Singapure and Sano, Nakoshizu, Japan \& Kawai, Japan; 236 pp.

ADHIKARI, M K (2009) Researches on the Nepalese mycoflora (Revised account on the history of mycological Explorations). Kathmandu, Nepal; $82 \mathrm{pp}$.

ADHIKARI, M K (2014) Mushrooms of Nepal. S.P. Printers, Jawalakhel, Lalitpur, Nepal; 340 pp (2nd edition). ADHIKARI, M K; DEVKOTA, S; TIWARI, R D (2005) Ethnomycological knowledge on uses of wild mushrooms in western and central Nepal. Our nature 3(1): 13-19.

AKPAJA, E O; OMOANGHES, S; ISIKHUEMHEN; OKHUOYA, J A (2003) Ethno-mycology and uses of edible and medicinal mushrooms among the Igbo people of Nigeria. Journal of Medicinal Mushrooms 5: 313-319. 
ALEXOPOULOS, C J; MIMS, C W (1993) Introductory Mycology. WEL, New Delhi, India; 632 pp (3rd edition).

ARYAL, H P; BUDHATHOKI, U (2013a) Buchwaldoboletus lignicola (Basidiomycetes), an Inedible Wild Mushroom New to Nepal. Our Nature 11(1): 31-35.

ARYAL, H P; BUDHATHOKI, U (2013b) The Genus Amanita (Pers.) in Lumbini zone, Nepal.

Scientific World 11(11): 113-120.

ARYAL, H P; BUDHATHOKI, U (2013c) Termitomyces albuminosus (Berk.) Heim. A New Fungal

Record from Arghakhanchi, Nepal. OAKS 9: 44-47.

ARYAL, H P; BUDHATHOKI, U; TIWARI, R D (2014a) Termitomyces microcarpus (Berk. \& broome)

R. Heim: A New records from Nepal. Journal of Mycology and Plant Pathology 44(1): 13-18.

ARYAL, H P; BUDHATHOKI, U; LAKHEY, P B (2014b) Phytochemical study of Termitomyces

robustus (Beeli) R. Heim in Nepal. Bulletin of Department of Plant Resource 36: 92-97.

ATRI, N S; KAUR, A; KOUR, H (2005) Wild mushrooms collection and identification. In RAI, R D; UPADHYAY, R C; SHARMA, S R (eds) Frontiers in mushroom biotechnology. NRCM Champaghat, Solan, India; pp 9-26.

ATRI, N S; KAUR, H (2003) Wild mushrooms collection and identification. Mushroom Research 14: 56-59.

BAKSHI, B K (1971) Indian Polyporaceae. Indian Council of Agriculture Resources, New Delhi, India; $256 \mathrm{pp}$.

BALKRISHNA, B; NAIR, M C (1994) Medicinal Mushrooms. In NAIR, M C; GOKULAPALAN, C; Luludas (eds) Advance in Mushroom Biotechnology. Scientific publishers, Jodhpur, India.

BHANDARY, HR (1980) Notes on some macro fungi of Nepal. Journal of Natural History Museum 4: $23-32$.

BHANDARY, H R (1991) Some edible and medicinal fungi from Dumre to Manag, Mustang and Pokhara. Journal of Natural History Museum 12(1-4): 47-60.

BHATTARAI, A (2013) Ethnomycological study of macrofungi in Sukhaura Hariyali Community forest, Makrahar VDC, Rupandehi, Nepal. M. Sc. dissertation, Central Department of Botany, Tribhuvan University, Kirtipur, Kathmandu, Nepal.

BILL, G F; COTTER, H V T (1989) Taxonomy and ethnomycology of Lactarius Sec. Dapetes (Russulaceae) in Nepal. Memoirs of the New York Botanical Garden 49: 192-197.

BOA, E (2004) Wild edible fungi: a global overview of their use and importance to people. Non-Wood Forest Products Series, No. 17. FAO, Rome, Italy; 157 pp.

CHRISTENSEN, M; DEVKOTA, S; BHATTARAI, S (2008a) Use of wild edible mushrooms in the Annapurna Conservation Area, Nepal. Journal of Mycology and Phytopathological Society of Nepal 1: 1-6.

CHRISTENSEN, M; BHATTARAI, S; DEVKOTA, S; LARSEN, H O (2008b) Collection and use of wild edible fungi in Nepal. Economic Botany 62 (1): 12-23.

DEVKOTA, S (2005) Mushroom diversity In Lumle (Kaski) and study of Clavariales from Lumle and vicinity of Kathmandu valley, Nepal. M. Sc. dissertation, Central Department of Botany, Tribhuvan University,Kirtipur, Kathmandu, Nepal. 
DICKINSON, C; LUCAS, J (1979) Encyclopedia of mushrooms. Orchid Publication, London; 295 pp.

ELLIOTT, J M (1971) Some methods for the statistical analysis of samples of benthic invertebrates. Sci. Publ. 25. Freshwater Biol. Ass., Ambleside, Westmorland.

FREUDENBERG, K S (2011) A manual for CRS field workers and partner. Maryland, USA.

Government of Nepal (2010) Climatological and agro meteorological records of Nepal. Ministry of Environment, Science and Technology. Department of Hydrology and Meteorology, Kathmandu, Nepal.

GUISSOU, K M L; LYKKE, A M; SANKARA, P; GUINKO, S (2008) Declining wild mushroom recognition and usage in Burkina Faso. Economic Botany 62: 530-539.

HARSH, N S K; RAI, B K; AYACHI, S S (1993) Forest fungi and tribal economy- a case study in Baiga tribe of Madhya Pradesh. Journal of Tropical Forest 9: 270-279.

HATTORI, T; ADHIKARI, M K; SUDA, T; DOI, Y (2002) A list of polypores (Basidiomycotina, Apyllophorales) collected in Jumla, Nepal. Bulletin of Natural Science Museum 28 (2): 27-38.

HEIM, R (1977) Termites et Champignons. Les termitophiles d'Afrique Noire at d'asie Meridionale. Paris, France: Societe Novelle des Edition. Boubee 11, Place Saint-Michel. Paris-6 (In French)..

IMAZEKI, R; OTANI, Y; HONGO, T (1988) Colored Illustration of Fungi of Japan. YAMAKEI Publishers Co. Ltd. Tokyo, Japan; 394 pp.

JOSHI, K; JOSHI, AR (1999) Ethnobotanical study of some wild mushrooms of the two valleys (Kathmandu and Pokhara) of Nepal. Ethnobotany, 11 (1\&2): 47-56.

KAMAT, N (1999) Ecotheological dimensions of termite hill. Govapuri Bull. Inst. Menezes Braganza 1: 3.

KHAREL, S (1999) New record of Lentinellus ursinus (Fr.) Kuhner. Abstracts of Third National Conference on Science and Technology. Kathmandu, Nepal; Abs: BSC 003: 64.

KIBBY, G (1979) Mushrooms and toadstools. Oxford University Press, London; 256 pp.

KUMMAR, A; BHATT, R P; LAKHANPAL, T N (1990) The Amanitaceae of India. Bishen Sing Mahendra Pal Singh, 23-A, Deharadun, India; 160 pp.

KUO, M (2006) Making spore prints. Retrieved from the Mushroom Expert. Com Web site: http://www. mushroomexpert.com/spore_print.html.

Lloyd, C G (1808) Mycological notes. Lloyd Library and Museum, Cincinnati, Ohio, USA; pp 1-75.

MANANDHAR, V; ADHIKARI, M K (2009) The family Sclerodermataceae: ectomycorhizal fungi from Nepal. Bulletin of Department of Plant Resource 31: 29-34.

MCKENENNY, M (1971) The savory wild mushroom. University of Washington press, USA.

MILLER, O K (1984) Mushroom of North America. E. P. Duttom Publishing Company Inc. New York, USA; $368 \mathrm{pp}$.

PACIONI, G (1985) The Mcdonald's encyclopedia of mushrooms and toadstools. Mcdonald \& Co. Ltd. London, UK; $511 \mathrm{pp}$.

PANDEY, N (2008) Mushroom Diversity in central Nepal: an ethno mycological Approach. Ph.D. dissertation, Central Department of Botany, Tribhuvan University, Kirtipur, Kathmandu, Nepal.

PHILLIPS, R (1981) Mushrooms and other fungi of Great Britain and Europe. Pan Book Ltd. London; 288 pp.

PURKAYASTHA, R P; CHANDRA, A (1985) Manual of Indian edible mushrooms. Jagendra Book Agency. 
New Delhi, India; 467 pp.

SACHERER, J (1979) The high altitude ethnoboyany of the Rolwaling Sherpas: a contribution of Nepalese studies. Journal of Research Centre for Nepal Asia Studies 6: 46-64.

SAGAR, A; CHAUHAN, A; SEHGAL, A K (2005) Ethnobotanical study of some wild edible mushrooms of tribal district Kinnaur of Himachal Pradesh. Indian Journal of Mushroom 23: 1-8.

SINGER, R (1986) The agaricales in modern taxonomy Bishen Singh Mahendra Pal Singh, Dehradun, India; $981 \mathrm{pp}$ (4th edition).

SINGH, S C (1966) Mushrooms. Deorali 4: 15-31

SINGH, S C; NISHA (1974) Exobasidium butleri in Nepal. Indian Phytopathology 27: 387-389.

SVRECK, M (1975) A colour guide to familiar mushrooms. Octopus Books, Lomdon; UK;183 pp.

TULLOSS, R E; BHANDARY, H R (1992) Amanita Chepangiana: a new species from Nepal. Mycotaxon 93: 25-31.

WATKINSON, S C; CARLILE AND, M C; GOODAY, G W (2000) The Fungi. Academic Press Limited, London, UK. 
TABLE 1. Wild mushrooms collected from different place of Rupandehi district, western Nepal.

\begin{tabular}{|c|c|c|c|c|c|}
\hline $\begin{array}{l}\mathbf{S} \\
\mathbf{N}\end{array}$ & $\begin{array}{c}\text { Sample } \\
\text { collection } \\
\text { number }\end{array}$ & $\begin{array}{l}\text { Scientific name } \\
\text { (Family) }\end{array}$ & Local name & Ecology & Application \\
\hline 1 & 1209561 & $\begin{array}{c}\text { Agaricus augustus Fr. } \\
\text { (Agaricaceae) }\end{array}$ & Kaile chyau & Soil,saprophytic & Used as vegetable \\
\hline 2 & 101065 & $\begin{array}{c}\text { Agaricus sylvicola } \\
\text { (Vittad.) Peck } \\
\text { (Plutaceae) }\end{array}$ & Sal chyau & Soil,saprophytic & not edible \\
\hline 3 & 100755 & $\begin{array}{c}\text { Amanita caesarea } \\
\text { (Scop.) Pers. } \\
\text { (Amanitaceae) } \\
\end{array}$ & Suntale chyau & Soil,mycorrhizae & Used as vegetable \\
\hline 4 & 100772 & $\begin{array}{c}\text { Amanita chepangiana } \\
\text { Tulloss \& Bhandary } \\
\text { (Plutaceae) }\end{array}$ & $\begin{array}{c}\text { Salleu, } \\
\text { cukhura phule } \\
\text { chyau }\end{array}$ & Soil,mycorrhizae & Used as vegetable \\
\hline 5 & 101064 & $\begin{array}{c}\text { Amanita fulva Fr. } \\
\text { (Amanitaceae) }\end{array}$ & Tahar & Soil,mycorrhizae & $\begin{array}{c}\text { Edible, not commonly } \\
\text { used }\end{array}$ \\
\hline 6 & 100773 & $\begin{array}{c}\text { Amanita pantharina (D } \\
\text { C.) Kromb. } \\
\text { (Amanitaceae) }\end{array}$ & Bhut chyau & Soil,mycorrhizae & Deadly poisonous \\
\hline 7 & 1008149 & $\begin{array}{l}\text { Armellaria mellea } \\
\text { (Vahl.: Fr.) Kummer. } \\
\text { (Marasmiaceae) }\end{array}$ & Todke chyau & $\begin{array}{l}\text { On decay log } \\
\text { from crevices } \\
\text { in moist shady } \\
\text { place,parasitic }\end{array}$ & $\begin{array}{l}\text { Used as vegetable/ } \\
\text { soup }\end{array}$ \\
\hline 8 & 1007214 & $\begin{array}{c}\text { Asterophora parasitica } \\
\text { (Bull.) Sing. } \\
\text { (Tricholomataceae) }\end{array}$ & $\begin{array}{l}\text { Chyau mathi } \\
\text { seto chyau }\end{array}$ & $\begin{array}{l}\text { In moist shady } \\
\text { place (above } \\
\text { the Russula } \\
\text { sp.),parasitic }\end{array}$ & Not edible \\
\hline 9 & 100742 & $\begin{array}{c}\text { Auricularia auricular- } \\
\text { judae (Bull.) Wettst } \\
\text { (=Hirneola auricular- } \\
\text { judae) } \\
\text { (Auriculariaceae) }\end{array}$ & Todke chyau & $\begin{array}{c}\text { On dead } \\
\text { twigs and } \\
\text { stumps, parasitic }\end{array}$ & $\begin{array}{l}\text { Used as vegetable/ } \\
\text { soup }\end{array}$ \\
\hline 10 & 1007120 & $\begin{array}{c}\text { Bjerkandera adusta } \\
\text { (Fr.) Karst. } \\
\text { (Hapilopilaceae) }\end{array}$ & Kane chyau & $\begin{array}{c}\text { On log }(T e r- \\
\text { minalia } \\
\text { alata),saprophytic }\end{array}$ & $\begin{array}{l}\text { Not edible, used as a } \\
\text { razor strop }\end{array}$ \\
\hline
\end{tabular}




\begin{tabular}{|c|c|c|c|c|c|}
\hline 11 & 1008329 & $\begin{array}{c}\text { Buchwaldoboletus lig- } \\
\text { nicola (Kallenb.) Pilat } \\
\text { (Bolataceae) }\end{array}$ & Dhyabre chyau & $\begin{array}{c}\text { On log (Shorea } \\
\text { robusta), sapro- } \\
\text { phytic }\end{array}$ & Not edible \\
\hline 12 & 100933 & $\begin{array}{l}\text { Cantharellua cibari- } \\
\text { uus (Fr.: Fr.) Fr. var. } \\
\text { amethysteus } \\
\text { (Tricholomataceae) }\end{array}$ & $\begin{array}{l}\text { Chyau mathi } \\
\text { seto chyau }\end{array}$ & $\begin{array}{l}\text { In moist shady } \\
\text { place, parasitic }\end{array}$ & Edible \\
\hline 13 & 1009397 & $\begin{array}{c}\text { Coltricia } \\
\text { cinninenea(Pers.) } \\
\text { Murrill (Hymenochae- } \\
\text { taceae) }\end{array}$ & Soli chyau & $\begin{array}{l}\text { On leaf mould } \\
\text { soil, saprophytic }\end{array}$ & Not edible \\
\hline 14 & 1009500 & $\begin{array}{l}\text { Coprinus comatus } \\
\text { (O.F. Mill.) Pers. } \\
\text { (Coprinaceae) }\end{array}$ & Gobre chyau & Soil,saprophytic & $\begin{array}{c}\text { Edible in young } \\
\text { stage.dried } \\
\text { powder given to the } \\
\text { child } \\
\text { with rice or milk } \\
\text { induced good sleep }\end{array}$ \\
\hline 15 & 100723 & $\begin{array}{l}\text { Coprinus plicatilis } \\
\text { (Curtis) Fr. } \\
\text { (Coprinaceae) }\end{array}$ & Payeje chyau & $\begin{array}{c}\text { On log (Acacea } \\
\text { catechu), sapro- } \\
\text { phytic }\end{array}$ & Poisonous \\
\hline 16 & 100722 & $\begin{array}{c}\text { Daldinia concentric } \\
\text { (Bolt.) Ces et de not. } \\
\text { (Polyporaceae) }\end{array}$ & $\begin{array}{l}\text { Dalle, kale } \\
\text { chyau }\end{array}$ & $\begin{array}{l}\text { On log (Dal- } \\
\text { bergia sissoo), } \\
\text { saprophytic }\end{array}$ & $\begin{array}{l}\text { Not edible,but me- } \\
\text { dicinal } \\
\text { value (used to } \\
\text { treat burns }\end{array}$ \\
\hline 17 & 100934 & $\begin{array}{c}\text { Flammulina velutipes } \\
\text { (Curtis) Sing. } \\
\text { (Marasmiaceae) }\end{array}$ & Patpate chyau & $\begin{array}{l}\text { On soil/Decaying } \\
\text { log, saprophytic }\end{array}$ & $\begin{array}{c}\text { Edible, but not } \\
\text { popularly } \\
\text { Used by the people }\end{array}$ \\
\hline 18 & 1007107 & $\begin{array}{c}\text { Ganoderma lucidium } \\
\text { P. Karst. } \\
\text { (Ganodermataceae) }\end{array}$ & Dadhu chyau & $\begin{array}{l}\text { Trunk (Bombax } \\
\text { ceiba),parasitic }\end{array}$ & $\begin{array}{c}\text { To remove evil spirit, } \\
\text { for used in decora- } \\
\text { tive } \\
\text { purpose }\end{array}$ \\
\hline 19 & 1007129 & $\begin{array}{l}\text { Grifola frondosa } \\
\text { (Dicks.) Gray } \\
\text { (Meripilaceae) }\end{array}$ & Giddha chyau & $\begin{array}{c}\text { Stump (Mallotus } \\
\text { phillippinensis), } \\
\text { parasitic }\end{array}$ & $\begin{array}{l}\text { Used to relief muscu- } \\
\text { lar pain }\end{array}$ \\
\hline 20 & 100715 & $\begin{array}{c}\text { Guepinia spathularia } \\
\text { (Schw.)Fr. } \\
\text { (Dacrymycetaceae) }\end{array}$ & Putali chyau & $\begin{array}{c}\text { On rotten } \\
\text { wood,saprophytic }\end{array}$ & Not edible \\
\hline 21 & 100759 & $\begin{array}{c}\text { Lentinus tigrinus (Bull.) } \\
\text { Fr. } \\
\text { (Polyporaceae) }\end{array}$ & Vedi chyau & $\begin{array}{c}\text { On stump } \\
\text { (Eugeina jambo- } \\
\text { lana), sapro- } \\
\text { phytic } \\
\end{array}$ & $\begin{array}{c}\text { Edible,but not prop- } \\
\text { erly } \\
\text { used }\end{array}$ \\
\hline
\end{tabular}


J. Nat. Hist. Mus. Vol. 29, 2015

\begin{tabular}{|c|c|c|c|c|c|}
\hline 22 & 1007127 & $\begin{array}{c}\text { Laetiporus sulphareus } \\
\text { Murrill } \\
\text { (Polyporaceae) }\end{array}$ & $\begin{array}{l}\text { Kath-phule } \\
\text { chyau }\end{array}$ & $\begin{array}{c}\text { Tree forest }(\mathrm{Tec}- \\
\text { tona grandis) } \\
\text { parasitic }\end{array}$ & $\begin{array}{c}\text { Young ones used for } \\
\text { culinary purpose }\end{array}$ \\
\hline 23 & 100704 & $\begin{array}{l}\text { Leucopaxillus gigan- } \\
\text { teus Boursier } \\
\text { (Tricholomataceae) } \\
\end{array}$ & Pyaje chyau & $\begin{array}{c}\text { open grasslandz, } \\
\text { saprophytic }\end{array}$ & $\begin{array}{c}\text { Edible, used as veg- } \\
\text { etable }\end{array}$ \\
\hline 24 & 1008118 & $\begin{array}{c}\text { Macrolepiota fuliginosa } \\
\text { (Barla) Bon } \\
\text { (Agaricaceae) }\end{array}$ & Gobbre chyau & Soil,saprophytic & Used as vegetable \\
\hline 25 & 1008330 & $\begin{array}{l}\text { Macrolepiota rhacodes } \\
\text { (Vittad.) Sing. } \\
\text { (Agaricaceae) }\end{array}$ & Gobbre chyau & Soil,saprophytic & Used as vegetable \\
\hline 26 & 100740 & $\begin{array}{c}\text { Marasmius oreades } \\
\text { (bolt.) Fr. } \\
\text { (Marasmiaceae) }\end{array}$ & Noune Chyau & Soil,saprophytic & $\begin{array}{l}\text { Edible but not com- } \\
\text { monly use }\end{array}$ \\
\hline 27 & 1008315 & $\begin{array}{l}\text { Nigroporus vinosa } \\
\text { (Berk.) Murrill } \\
\text { (Fomotopsidaceae) }\end{array}$ & Jhule chyau & $\begin{array}{c}\text { On log } \\
\text { (Syzygium } \\
\text { cumini),parasitic/ } \\
\text { saprophytic } \\
\end{array}$ & Inedible \\
\hline 28 & 100832 & $\begin{array}{c}\text { Psathyrella candolee- } \\
\text { ana (Fr.) Maire } \\
\text { (Coprinaceae) } \\
\end{array}$ & Todke Chyau & \begin{tabular}{|c|}
$\begin{array}{c}\text { on log (Dalbergia } \\
\text { latifolia), sapro- } \\
\text { phytic }\end{array}$ \\
\end{tabular} & Inedible \\
\hline 29 & 100711 & $\begin{array}{c}\text { Pycnoporus cinnaba- } \\
\text { rinus (Jacq.) P. Karst. } \\
\text { (Polyporaceae) }\end{array}$ & Sindure chyau & $\begin{array}{l}\text { Stump (Syzy- } \\
\text { gium cumini), } \\
\text { saprophytic }\end{array}$ & $\begin{array}{l}\text { Medicine,for relief } \\
\text { ear } \\
\text { pain,mumps }\end{array}$ \\
\hline 30 & 120735 & $\begin{array}{c}\text { Ramaria aurea (Fr.) } \\
\text { Quel. } \\
\text { (Ramariaceae) } \\
\end{array}$ & Thakre chyau & \begin{tabular}{|c|} 
Moist shady \\
place on pine \\
tree,mycorrhizal \\
\end{tabular} & $\begin{array}{c}\text { Used as vegetable, } \\
\text { and also sold in local } \\
\text { market }\end{array}$ \\
\hline 31 & 100975 & $\begin{array}{l}\text { Ramaria falva (Fr.) } \\
\text { Quel.(Ramariaceae) }\end{array}$ & Thokre chyau & \begin{tabular}{|c|} 
Moist shady \\
place on pine \\
tree,mycorrhizae
\end{tabular} & $\begin{array}{c}\text { Used as vegetable, } \\
\text { and also sold in local } \\
\text { market }\end{array}$ \\
\hline 32 & 1008316 & $\begin{array}{c}\text { Ramariopsis kunzei } \\
\text { (Donk) Corner } \\
\text { (Gomphaceae) }\end{array}$ & Panje chyau & $\begin{array}{c}\text { Stump (Mallotus } \\
\text { phillippinensis), } \\
\text { saprophytic } \\
\end{array}$ & Inedible \\
\hline 33 & 100779 & $\begin{array}{c}\text { Russula emetica } \\
\text { (Schaeff.) Pers. } \\
\text { (Russulaceae) }\end{array}$ & Ratteuo & Litter,mycorrhizae & $\begin{array}{c}\text { Poisonous medicine } \\
\text { that } \\
\text { cause vomiting }\end{array}$ \\
\hline 34 & 1008350 & $\begin{array}{c}\text { Russula foetens Pers. } \\
\text { (Russulaceae) }\end{array}$ & Gandhe chyau & Soil,mycorrhizae & Poisonous \\
\hline 35 & 100751 & $\begin{array}{c}\text { Russula nigricans Fr. } \\
\text { (Russulaceae) }\end{array}$ & Handi chyau & Soil,mycorrhizae & Edible,pickle \\
\hline
\end{tabular}


Aryal : Diversity of Wild Mushrooms in

\begin{tabular}{|c|c|c|c|c|c|}
\hline 36 & 101002 & $\begin{array}{l}\text { Schizophyllum com- } \\
\text { mune (Fr.:Fr.) Gerb. } \\
\text { (Schizophyllaceae) }\end{array}$ & Pankha chyau & $\begin{array}{l}\text { decayed wood: } \\
\text { Shorea robusta, } \\
\text { saprophytic }\end{array}$ & $\begin{array}{l}\text { Edible,religious, } \\
\text { cultural, } \\
\text { culinary purpose }\end{array}$ \\
\hline 37 & 1009152 & $\begin{array}{c}\text { Scleroderma bovista } \\
\text { Pers. } \\
\text { (Sclerodermataceae) }\end{array}$ & $\begin{array}{l}\text { Alu chyau, } \\
\text { Ptteu }\end{array}$ & Soil,mycorrhizae & $\begin{array}{l}\text { vegetable, edible/ } \\
\text { medicinal }\end{array}$ \\
\hline 38 & 1007317 & $\begin{array}{c}\text { Scleroderma citrinum } \\
\text { Fr. (Sclerodermata- } \\
\text { ceae) }\end{array}$ & Dalle chyau & Soil,mycorrhizae & $\begin{array}{c}\text { Inedible/ } \\
\text { medicinal,causes } \\
\text { gastric disorders or } \\
\text { acute indigestion }\end{array}$ \\
\hline 39 & 100748 & $\begin{array}{c}\text { Sparassis crispa } \\
\text { (Wulfen) Fr. } \\
\text { (Sparadiaceae) }\end{array}$ & Kauli chyau & $\begin{array}{c}\text { On log (Tectona } \\
\text { grandis), parasitic }\end{array}$ & $\begin{array}{c}\text { Used as vegetable } \\
\text { soup }\end{array}$ \\
\hline 40 & 1010525 & $\begin{array}{c}\text { Termitomyces albu- } \\
\text { minosus (Berk.) R. } \\
\text { Heim } \\
\text { (Tricholomataceae) }\end{array}$ & Bemtee & $\begin{array}{c}\text { Termites } \\
\text { nest,obligatory } \\
\text { symbionts }\end{array}$ & $\begin{array}{l}\text { Soup used for the } \\
\text { remedy of measles, } \\
\text { yellow fevers etc. }\end{array}$ \\
\hline 41 & 1010530 & $\begin{array}{c}\text { Termitomyces clypea- } \\
\text { tus R. Heim } \\
\text { (Tricholomataceae) }\end{array}$ & $\begin{array}{c}\text { Dhamere } \\
\text { chyau,Vemti }\end{array}$ & $\begin{array}{c}\text { Termites } \\
\text { nest,obligatory } \\
\text { symbionts } \\
\end{array}$ & $\begin{array}{l}\text { Edible,medicinal, } \\
\text { fever. miseales }\end{array}$ \\
\hline 42 & 1007119 & $\begin{array}{l}\text { Termitomyces eurrhi- } \\
\text { zus (Berk.) R. Heim } \\
\text { (Tricholomataceae) }\end{array}$ & $\begin{array}{c}\text { Dhamere } \\
\text { chyau, Bagale } \\
\text { chyau } \\
\end{array}$ & $\begin{array}{c}\text { Termites } \\
\text { nest,obligatory } \\
\text { symbionts }\end{array}$ & $\begin{array}{c}\text { Edible,medicinal, } \\
\text { fever } \\
\text { miseales }\end{array}$ \\
\hline 43 & 1008133 & $\begin{array}{c}\text { Termitomyces mi- } \\
\text { crocarpus (Berk. \& } \\
\text { Broome) R. Heim } \\
\text { (Tricholomataceae) }\end{array}$ & Jhari/Rai & $\begin{array}{c}\text { Termites } \\
\text { nest,obligatory } \\
\text { symbionts }\end{array}$ & $\begin{array}{l}\text { Edible,medicinal, } \\
\text { soup used as tonic }\end{array}$ \\
\hline 44 & 100701 & $\begin{array}{l}\text { Trametes hirsute (Fr.) } \\
\text { Pilat [= Coriolus hirsu- } \\
\text { tus (Fr.) Quel.] } \\
\text { (Polyporaceae) }\end{array}$ & Kathe chyau & $\begin{array}{c}\text { Rotten log } \\
\text { (Shorea robusta), } \\
\text { saprophytic }\end{array}$ & Not edible \\
\hline 45 & 1107979 & $\begin{array}{c}\text { Volvorella bombaycina } \\
\text { (Schaeff.ex Fr.) Sing. } \\
\text { (Plutaceae) }\end{array}$ & Chiple chyau & $\begin{array}{c}\text { On wood (Adena } \\
\text { cordifolia), sapro- } \\
\text { phytic }\end{array}$ & Used as vegetable \\
\hline 46 & 1109856 & $\begin{array}{c}\text { Volvorella volvacea } \\
\text { (Bull.:Fr.) Sing. } \\
\text { (Plutaceae) }\end{array}$ & Parale chyau & $\begin{array}{c}\text { decomposed } \\
\text { paddy straw, } \\
\text { saprophytic } \\
\end{array}$ & Used as vegetable \\
\hline
\end{tabular}

